\title{
First molecular evidence of cross-species induction of metalloprotease gene expression in Vibrio strains pathogenic for Pacific oyster Crassostrea gigas involving a quorum sensing system
}

\author{
Sophie De Decker ${ }^{a,}{ }^{*}$, Yann Reynaud ${ }^{a}$, Denis Saulnier ${ }^{b}$ \\ a Laboratoire de Génétique et Pathologie, Ifremer, avenue de Mus du Loup, 17390 La Tremblade, France \\ ${ }^{\mathrm{b}}$ Centre Ifremer de Tahiti, BP 7004, 98719 Taravao, Tahiti, Polynésie, France \\ Present address : NOAA, NEFSC, 212 Rogers Av, Milford, CT 06460, USA. \\ *: Corresponding author : Sophie De Decker, Tel.: + 1203882 6500, + 33546762610 ; fax: + 12038826570 , \\ + 335467626 11. ; email address : sophiededecker@yahoo.com ; Sophie.Dedecker@noaa.gov
}

\begin{abstract}
:
The aim of that study was to explore the hypothesis that a quorum sensing mechanism modulates metalloprotease gene expression of two Vibrio species pathogenic for oyster, at intraspecific (Vibrio splendidus) and interspecific ( $V$. splendidus affecting $V$. aestuarianus) levels. Metalloprotease activities (Vsm for V. splendidus LGP32 and Vam for V. aestuarianus 02/041) and growth curves obtained by real-time PCR assay revealed cell density-dependent metalloprotease inductions triggered between $12 \mathrm{~h}$ and $16 \mathrm{~h}$ of culture. A quorum sensing assay was then developed using a conditioned medium prepared from supernatant of a mutant strain of $V$. splendidus LGP32 unable to produce metalloprotease. Specific real-time qPCR assays targeting metalloprotease genes $v s m$ and vam were performed. A relative increase in expression was observed for vsm and, particularly, vam in the presence of the conditioned medium, probably controlled by a quorum sensing system. The study revealed intraspecific and interspecific modulation of expression in metalloprotease genes $v s m$ and vam in $V$. splendidus and $V$. aestuarianus.
\end{abstract}

Our experiments showed for the first time that $V$. splendidus is able to produce an autoinducer-like substance that displays intra- and interspecific effects on the expression of two different metalloprotease genes: vsm and vam.

\section{Highlights}

$V$. splendidus increases the expression level of $V$. aestuarianus metalloprotease vam. This mechanism is probably linked with quorum sensing. We show for the first time interspecific communication between these two Vibrio.

Keywords: Quorum sensing ; Crassostrea gigas ; Vibrio ; Metalloprotease ; Gene expression 


\section{Introduction}

Vibrio splendidus and $V$. aestuarianus are two ubiquitous bacteria widely represented in marine ecosystems (Thompson, et al., 2005) and associated with the endogenous flora of various fish and shellfish (Arias, et al., 1999; Azandégbé, et al., 2010; Beaz Hidalgo, et al., 2008; GomezGil, et al., 2010; Le Roux, Austin, 2006; Macián, et al., 2000; Montes, et al., 2006; Montes, et al., 2003; Pujalte, et al., 1999). These two Vibrio have been reported to be frequently involved in summer mortality events of the cultured Pacific oyster Crassostrea gigas in France in the last decade and most strains isolated from oyster during such summer mortality events were found to be virulent in experimental infections made by injection (Garnier, et al., 2007; Gay, et al., 2004a; Le Roux, et al., 2004; Saulnier, et al., 2009; Saulnier, et al., 2010).

Virulence processes of these two species are still not fully understood, but metalloproteases of the strains V. splendidus LGP32 (Vsm) and V. aestuarianus 01/032 (Vam) have been described as virulence factors (Binesse, et al., 2008; Labreuche, et al., 2010; Le Roux, et al., 2007). Furthermore, culture supernatants fluids from most of the virulent $V$. splendidus and $V$. aestuarianus strains isolated during abnormal summer mortality of $C$. gigas also have metalloprotease activities (Saulnier, et al., 2010). Indeed, the toxicity of extracellular products (ECPs) containing Vsm and of purified Vsm protein from V. splendidus LGP32 has been confirmed by experimental infection of oyster (Le Roux, et al., 2007) and tests on snail and mouse fibroblastic cell lines, while the LGP32- $\Delta$ vsm- $\Delta 1062$ mutant ECPs had dramatically reduced toxicity (Binesse, et al., 2008). Concerning $V$. aestuarianus 01/032, a recombinant plasmid carrying the gene encoding the metalloprotease Vam was transferred to the nonvirulent $V$. splendidus-related strain LMG20012T, which is naturally devoid of any protease activity (Labreuche, et al., 2010). Recombinant LMG20012T ECPs exhibited toxicity both in vivo on C. gigas oyster and in vitro on oyster hemocytes. Both V. splendidus LGP32 and $V$. aestuarianus $02 / 041$ strains produce metalloproteases sharing 71 and $68 \%$ of identity in their nucleotide and amino acid sequences respectively.

Furthermore, a complete genome analysis of the strain V. splendidus LGP32 (Le Roux, et al., 2009) revealed many genes potentially involved in quorum sensing mechanisms (Grimes, et al., 2009) and therefore potentially modulating virulence gene expression. Quorum sensing is a bacterial regulation system using extracellular signal molecules known as autoinducers to control expression of particular genes encoding bioluminescence, conjugation, virulence and biofilms (Bassler, 2002; Defoirdt, et al., 2005; Fuqua, Greenberg, 1998; Kaprelyants, Kell, 1996; Ren, et al., 2001; Schauder, Bassler, 2001; Wirth, et al., 1996). Synthesis of extracellular signal molecules appears critical for this process, and increases with bacterial concentration up to a significant threshold that induces the expression of target genes (Miller, Bassler, 2001; Waters, Bassler, 2005). Different quorum sensing systems have been described, notably depending on the signal molecules implicated: autoinducer Al-2, cholerae autoinducer-1 (CAl-1), acylated homoserine lactone (AHL), oligopeptides, quinolones, cyclic dipeptides and $\mathrm{y}$-butyrolactones (McDougald, et al., 2007). For example, V. harveyi bioluminescence, siderophore expression, a type III secretion system and a metalloprotease have all been proven to be modulated by quorum sensing mechanisms (Henke, Bassler, 2004b). Three different mechanisms involving three types of autoinducers and receptors have been found in this species: Al-2 (encoded by luxS, luxQ, luxP), CAl-1 (encoded by cqsA, cqsS) and AHL (encoded by luxM, luxN) (Defoirdt, et al., 2007). Based on the complete genome sequence of $V$. splendidus LGP32, it seems that this strain shares the three quorum sensing systems found in $V$. harveyi, which are based on three different autoinducers: AHL, CAl-1 and Al-2 1. In V. aestuarianus 02/041, a few genes 
linked to quorum sensing have been found in its partial genome sequence (luxS, luxO, IuxU and luxR - J.L. Nicolas, pers. com., Genoscope project, http://www.genoscope.cns.fr/spip/Wholegenome-sequencing-of-Vibrio.html, in progress).

A strong synergistic effect of virulence has been described in experimental infections in which both of these strains were injected simultaneously rather than singly at the same dose (Saulnier, et al., 2010). In the present study, we explored the hypothesis of quorum sensing mechanisms involved in the modulation of expression of vsm and vam metalloprotease genes at both protein and transcriptomic levels, evaluating strains i/ intraspecifically ( $V$. splendidus) and ii/ interspecifically ( $V$. splendidus / $V$. aestuarianus). Expression of the two metalloprotease genes vsm and vam were quantified by real-time qPCR assays using two different growth media: Marine Broth on the one hand, and a conditioned medium prepared from a culture of a mutant strain of $V$. splendidus LGP32 unable to produce metalloprotease in culture supernatant fluids on the other hand.

\section{Material and Methods}

\subsection{Growth and metalloprotease activity curves}

\subsubsection{Bacterial strains and culture conditions}

All strains used in this study (listed in Table 1) were cultured in Marine Broth (MB, Difco). For 02/041 and LGP32-GFP growth curves and proteolytic activity curves of the culture supernatant fluid (CSF), pure cultures were prepared in parallel as follows. Seven $\mathrm{ml} \mathrm{MB}$ were inoculated with colonies isolated on MB 15\% agar medium plates from bacterial stock culture stored at $80^{\circ} \mathrm{C}$ and prepared as $15 \%(\mathrm{v} / \mathrm{v})$ glycerol suspensions in $\mathrm{MB}$. Bacteria were grown at $20^{\circ} \mathrm{C}$ for $24 \mathrm{~h}$ under constant shaking. The expected $10^{9}$ bacteria per $\mathrm{ml}$ concentrations of bacterial suspensions at stationary phase were checked by the plate counting method. A 75- $\mu$ l subsample of this bacterial stationary phase suspension was used to inoculate a $250 \mathrm{ml}$-flask of MB. This $250 \mathrm{ml} \mathrm{MB}$ culture was divided 30 times into $7 \mathrm{ml}$ cultures that were maintained under constant shaking. Three tubes were sampled as biological triplicates at $3 \mathrm{~h}, 5 \mathrm{~h}, 7 \mathrm{~h}, 9 \mathrm{~h}, 10.5 \mathrm{~h}$, $12 \mathrm{~h}, 16 \mathrm{~h}, 20 \mathrm{~h}, 45 \mathrm{~h}$ and $141 \mathrm{~h}$ post-inoculation for bacterial quantification using a qPCR assay and for the assessment of the proteolytic activity in the CSF.

\subsubsection{Real-time qPCR assays to quantify bacteria in pure cultures}

Standard curves for the quantification of each strain were established using 1:10 serial dilutions of $V$. splendidus LGP32-GFP and $V$. aestuarianus $02 / 041$ cells obtained from $20 \mathrm{~h}$ stationary phase pure cultures. Nine hundred $\mu \mathrm{L}$ of each dilution were centrifuged at $10000 \mathrm{~g}$ for $5 \mathrm{~min}$ at $20^{\circ} \mathrm{C}$. The resulting cell pellets were resuspended in $900 \mu \mathrm{l}$ ultra pure water (Sigma). Total DNA was extracted from $100 \mu \mathrm{l}$ by boiling for $10 \mathrm{~min}$ at $98^{\circ} \mathrm{C}$ and then placing at $4^{\circ} \mathrm{C}$ for a few minutes before PCR assay. Five $\mu \mathrm{l}$ of the solution were used in triplicate as PCR template. The quantification of bacterial cells by real-time PCR was compared each time with the enumeration of the bacterial cells used for DNA extractions, done using the plate counting method. 
To obtain growth curves, this same DNA extraction procedure was applied to $200-\mu$ l samples of the pure cultures. Two real-time qPCR assays were then used for the specific quantification of $V$. splendidus LGP32-GFP and V. aestuarianus 02/041 strains in pure culture samples, as already described in (De Decker, Saulnier, 2011; Saulnier, et al., 2009). Both qPCR were based on Taqman ${ }^{\circledR}$ chemistry and targeted the GFP and dnaJ genes, respectively. The sequences of oligonucleotides and Taqman ${ }^{\circledR}$ probes used here are given in (De Decker, Saulnier, 2011). Real-time PCR assay was conducted on an MX3000 Thermocycler (Stratagene) using a Brilliant QPCR Core Reagent Kit (Stratagene). The thermal cycle and Ct analysis were carried out in exactly the same way as described by (Saulnier, et al., 2009). Each reaction was run in triplicate in a final volume of $25 \mu \mathrm{l}$, containing various concentrations of DNA sample $(5 \mu \mathrm{l}), 5 \mathrm{mmol} \mathrm{I}^{-1}$

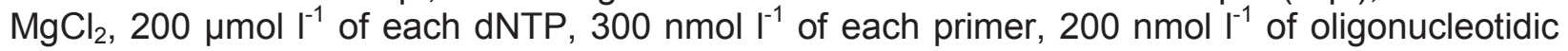
probe and 1.25 units of Hot Start Sure Taq polymerase (Qiagen).

\subsubsection{Metalloprotease activity in culture supernatant fluids}

Culture supernatant fluids (CSF) were obtained by centrifugation of each bacterial suspension at $10000 \mathrm{~g}$ for $5 \mathrm{~min}$. Proteolytic activity in $250 \mu \mathrm{l} \mathrm{CSF}$ was measured in the ten samples covering the two strains 02/041 and LGP32-GFP grown in pure cultures (see above) and determined using azocasein (Sigma Chemical Co., St. Louis, MO) as a substrate, according to the method described in (Saulnier, et al., 2010). To confirm metalloprotease activity in culture supernatants, CSF were assayed with azocasein under the same conditions, with an additional CSF preincubation step at $20^{\circ} \mathrm{C}$ for $30 \mathrm{~min}$ in the presence of $8 \mathrm{mmol} \mathrm{I}^{-1} 10$-phenanthroline as a metalloprotease inhibitor.

\subsection{Quorum sensing assay}

\subsubsection{Preparation of cell-free conditioned medium and cultures}

To test the hypothesis that a quorum-sensing system regulates metalloprotease genes expression, V. splendidus LGP32 $\Delta v s m-\Delta 1062$ was grown in $100 \mathrm{ml} \mathrm{MB}$ at $20^{\circ} \mathrm{C}$ for $20 \mathrm{~h}$ under constant shaking. Cells were centrifuged at $3500 \mathrm{~g}$ for $15 \mathrm{~min}$ and the resulting supernatant was filtered through a $0.22 \mu \mathrm{m}$-pore-size acetate filter. This cell-free and non-proteolytically active supernatant from stationary phase cultures of the mutant strain was used as culture media for both $V$. splendidus LGP32-GFP and $V$. aestuarianus 02/041 strains.

To examine the effects of such a conditioned medium on metalloprotease gene expression, several cell pellets from centrifuged stationary phase cultures of $V$. splendidus LGP32-GFP and $V$. aestuarianus $02 / 041$ were prepared for expected final concentrations of $10^{5}$ and $10^{8} \mathrm{CFU} \mathrm{ml}^{-1}$ and resuspended in $7 \mathrm{ml}$ of either conditioned medium or MB medium.

For the quantification of bacteria and the analysis of vsm and vam gene expression levels by real-time PCR, Total DNA (see procedures above) and RNA (see procedures below) were extracted from $1.5 \mathrm{~h}$ post-inoculum cultures, respectively. 


\subsubsection{Analysis of $v s m$ and vam gene expression in pure cultures by real-time qPCR}

Total bacterial RNA was isolated from $500 \mu \mathrm{l}$ of MB or conditioned pure culture (see above) added with $1 \mathrm{ml}$ of the stabilizing and protecting RNA Bacteria Reagent (Qiagen). Bacteria RNA extractions were performed using a commercial kit (RNeasy Mini Kit, Qiagen) including a DNase treatment.

Culture samples were centrifuged at $10000 \mathrm{~g}$ for $5 \mathrm{~min}$. Bacterial disruption and lysate homogenization were performed in three steps: i/ using an appropriate buffer containing proteinase $\mathrm{K}\left(10 \mathrm{mg} \mathrm{HI}^{-1}\right)$ and lysozyme in DEPC-treated water, ii/ using an appropriate buffer containing $\beta$-mercaptoethanol $\left(10 \mu \mathrm{ml}^{-1}\right)$ and iii/ adding $250 \mu \mathrm{l}$ absolute ethanol. Seven hundred $\mu \mathrm{l}$ of these lysates were purified according to manufacturers' instructions (RNeasy Mini Kit, Qiagen).

The expression levels of metalloprotease genes vsm and vam were determined by real-time qPCR on an MX3000 Thermocycler (Stratagene). Approximately $100 \mathrm{ng}$ of RNA transcripts were reverse-transcribed in a final volume of $20 \mu \mathrm{l}$, using an optimized blend of random primers (Qiagen) and a mix of two reverse transcriptases (Quantiscript Reverse Transcriptase, Qiagen), according to the manufacturer's instructions (Quantitect Reverse Transcription Kit, Qiagen). cDNAs were amplified by real-time PCR using specific primers designed with Primer 3 software, under general conditions of $60^{\circ} \mathrm{C}$ optimal annealing temperature for pairs of oligonucleotides, and an amplicon size of $159 \mathrm{bp}$ (Table 2). The cDNA regions for primer design were deduced from a GenBank targeted sequence alignment. The primers were checked for specificity using a BLAST search to determine homology with known sequences. Two primer pairs per gene were tested for their efficacy and specificity in real-time PCR, leading to the selection of a primer pair for the subsequent gene expression analysis done in this study.

The real-time PCR assay was performed in triplicate in a total volume of $25 \mu \mathrm{l}$, using Brilliant SYBR Green qPCR master mix (Stratagene), with $200 \mathrm{nmol} \mathrm{I}^{-1}$ of each primer and exactly the same thermal cycle conditions as described in (De Decker, Saulnier, 2011). PCR efficiencies $\left(E=10^{(-1 / s l o p e)}\right)$ and linear regressions were calculated by drawing standard curves from a serial dilution analysis of cDNAs obtained from overnight cultures of either $V$. splendidus LGP32-GFP or $V$. aestuarianus 02/041 strains, testing each dilution in triplicate. Normalized relative gene expression levels were calculated with the formula: $F=(E+1)^{40-C t} / N$ where i/ $E=q P C R$ efficacy, ii/ threshold cycle $(\mathrm{Ct})$ value corresponds to the PCR cycle number at which an increase in reporter fluorescence above the baseline signal was first detected, iii/ sensitivity of qPCR metalloprotease gene detection is obtained at $\mathrm{Ct}=40$ and arbitrarily considered to correspond to one copy of the targeted gene present in the qPCR well, iv/ $\mathrm{N}$ is the number of $10^{9} \mathrm{CFU}$ equivalent genomes determined by absolute real time PCR quantification of 02/041 and LGP32 strains. 


\section{Results}

\subsection{Growth curves and metalloprotease activity}

Standard curves of the virulent LGP32-GFP and 02/041 strains are shown in Figure 1. The $V$. splendidus LGP32-GFP linear regression curve had a regression coefficient $\left(r^{2}\right)$ of 0.997 and a PCR reaction efficacy of $103.9 \%$. The $V$. aestuarianus $02 / 041$ linear regression curve had an $r^{2}$ of 0.998 and a PCR reaction efficacy of $103.6 \%$.

The growth curves quantified by real-time qPCR, show similar general patterns. Strains reached comparable concentrations after $20 \mathrm{~h}$ culture (V. aestuarianus: $2.310^{8}$ CFU-equivalent

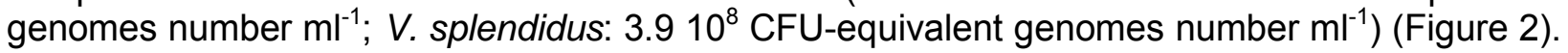
Similar curves were obtained by the plate counting method (data not shown). The linearity of the exponential phase of growth enabled us to calculate generation times, which were of $41 \mathrm{~min}$ for $V$. splendidus LGP32-GFP and $60 \mathrm{~min}$ for $V$. aestuarianus $02 / 041$ in these experimental conditions.

Large differences in metalloprotease activity were found between the strains from $16 \mathrm{~h}$ culture time. Vibrio aestuarianus $02 / 041$ produced 5.5 times more metalloprotease than $V$. splendidus LGP32-GFP, i.e. 433 units per number $\left(\times 10^{9}\right)$ of cells in the $16 \mathrm{~h} \mathrm{~V}$. aestuarianus 02/041 CSF and 79 units per number $\left(\times 10^{9}\right)$ of cells in the $16 \mathrm{~h} \mathrm{~V}$. splendidus LGP32-GFP CSF. Production by $V$. splendidus LGP32-GFP was almost stable after $16 \mathrm{~h}: 66 \pm 4$ units per number $\left(\times 10^{9}\right)$ of cells, whereas $V$. aestuarianus $02 / 041$ production increased logarithmically from $16 \mathrm{~h}$ to $141 \mathrm{~h}$ to reach $1016 \pm 18$ units per number $\left(\times 10^{9}\right)$ of cells.

For both bacteria, metalloprotease activity was only detectable after $12 \mathrm{~h}$ or more of culture and was particularly observed in the $16 \mathrm{~h}$ cultures. These cell density-dependent metalloprotease inductions were triggered at concentrations between $2.910^{8}$ and $3.810^{8}$ CFU-equivalent genomes number $\mathrm{ml}^{-1}$ for $V$. splendidus LGP32-GFP and between $7.210^{7}$ and $1.910^{8} \mathrm{CFU}$ equivalent genomes number $\mathrm{ml}^{-1}$ for $V$. aestuarianus 02/041.

\subsection{Quorum sensing assay}

Two kinds of media were inoculated at $10^{5}$ and $10^{8} \mathrm{CFU} \mathrm{ml}{ }^{-1}$ with either $V$. splendidus LGP32GFP or $V$. aestuarianus 02/041: Marine Broth and the conditioned medium prepared from the stationary phase of mutant cultures (see Materials and Methods). Bacteria in $1.5 \mathrm{~h}$ cultures were quantified by real-time qPCR targeting recombinant $g f p$ and dnaJ genes.

PCR primers were designed to specifically quantify the expression of metalloprotease genes $v s m$ and vam. Real-time qPCR efficacies and $r^{2}$ correlations were calculated by drawing standard curves, giving $99.3 \%$ and 0.952 , respectively for vsm, and $103.7 \%$ and 0.998 for vam. Size of amplified PCR products was verified by visualizing the expected $159 \mathrm{bp}$ amplicon on agarose gel electrophoresis (data not shown).

The normalized relative gene expression levels were calculated using the formula: $F=(E+1)^{40-}$ $\mathrm{Ct} / \mathrm{N}$. No expression of $v s m$ and vam was measured in $\mathrm{MB}$ at the lower bacterial concentration (Figure 3), while significant relative gene expression $F$ levels were measured in $M B$ at the 
higher concentration for both $V$. splendidus LGP32-GFP and $V$. aestuarianus 02/041: 8 and 1.1 $10^{4}$, respectively.

In the comparison of $\mathrm{MB}$ and conditioned media, no expression of vsm was measured at the lower bacterial concentration in either of the media, while an increase in $\mathrm{F}$ value was observed (from 8 to 35) at the higher concentration, corresponding to an increase in the quantity of vsm transcripts by a factor of 4.4 in the conditioned medium.

For $V$. aestuarianus 02/041, no metalloprotease gene expression was detected at lower bacterial concentrations in MB medium whereas a significant increase by a factor of at least 2.4 $10^{5}$ was observed at a similar concentration in the conditioned medium. A higher $\mathrm{F}$ value was also found at the higher concentration ( $F$ value of $1.110^{4}$ in MB and $2.410^{6}$ in the conditioned medium) which corresponds to an increase of the transcript levels by a factor of 218 . So the relative expression level of vam at the fold higher bacterial concentration is $6.710^{4}$ higher than vsm in the conditioned medium.

\section{Discussion}

In this study we explored the modulation of vsm and vam gene expression using a conditioned medium hypothetically containing autoinducers that modulate virulence factors via a quorum sensing system. Several different arguments led us to hypothesize that such a quorum sensing system could be at work, modulating metalloproteases in $V$. splendidus and $V$. aestuarianus:

i/ Vsm and Vam metalloproteases have been described as important virulence factors in ECPs of V. splendidus LGP32 and V. aestuarianus 01/032, respectively (Binesse, et al., 2008; Labreuche, et al., 2010; Le Roux, et al., 2007). Furthermore, metalloprotease activities have been characterized in most of the virulent $V$. splendidus and $V$. aestuarianus strains isolated during summer mortality events of oyster Crassostrea gigas in France in a large scale epidemiological survey conducted between 2003 and 2007 (Saulnier, et al., 2010). Metalloprotease gene expression modulated by quorum sensing has been described in a number of different Vibrio species: V. cholerae, V. harveyi, V. vulnificus and V. anguillarum (Denkin, Nelson, 2004; Henke, Bassler, 2004b; Mok, et al., 2003; Shao, Hor, 2001; Zhu, et al., 2002).

ii/ Natural co-infection by $V$. splendidus and $V$. aestuarianus has been described, as have synergistic effects in experimental infections, observed both intra-specifically between different V. splendidus strains (Gay, et al., 2004b) and inter-specifically between V. splendidus and $V$. aestuarianus (Saulnier, et al., 2010). Such synergistic effects could be linked to bacterial communication via a quorum sensing system that modulates virulence factor expression.

iii/ A quorum sensing system was identified in silico using the complete genome sequence of V. splendidus LGP32 (Le Roux, et al., 2009). Concerning V. aestuarianus 02/041, the partially annotated genome sequencing has already allowed the identification of an autoinducer synthase AI-2-like, signal transducer and transcriptional regulator (unpublished results). CAI-1 is produced by a number of Vibrio species and this system is presumed to be used for intragenus communication whereas $\mathrm{Al}-2$ seems to be linked to interspecies quorum sensing communication (Higgins, et al., 2007). Thus, because of their genome content, both $V$. splendidus and $V$. aestuarianus could putatively have the capacity to communicate interspecifically via a quorum sensing mechanism. 
iv/ Some experimental observations based on the analysis of both growth curves and metalloprotease production curves (Figure 2) support the existence of a quorum sensing system in both $V$. splendidus and $V$. aestuarianus strains used in this study.

$V$. splendidus and $V$. aestuarianus growth curves showed very slight differences in our culture conditions; in particular, there was a shorter generation time in V. splendidus LGP32-GFP than in $V$. aestuarianus 02/041: about $40 \mathrm{~min}$ and $60 \mathrm{~min}$, respectively. After $20 \mathrm{~h}$ of culture, both strains reached the stationary phase at similar concentrations between $10^{8}$ and $10^{9} \mathrm{CFU} \mathrm{ml}{ }^{-1}$. The bacterial quantification by qPCR was compared with plate counts for each point in time studied and showed convergent results until $45 \mathrm{~h}$ of culture. This last result suggests that no bias of quantification by qPCR occurred, since this latter technique is able to detect dead as well as live bacteria if they still contain an intact genome. Nevertheless, higher accuracy and narrower standard deviations were obtained from the biological triplicates using qPCR assay compared with the plate counting method, which was more laboratory intensive. In the first $45 \mathrm{~h}$ of growth, the qPCR assay used in this study was deemed useful because of its rapidity, specificity, accuracy and reliability.

Our method for measuring metalloprotease production is based on the assessment of azocaseinase activity, which is assumed to be due to a metalloprotease-like enzyme due to the effects of zinc-dependent metalloprotease inhibitors such as phenanthrolein. First, it was interesting to notice that metalloprotease-like activity measured in $\mathrm{V}$. aestuarianus 02/041 CSF at $45 \mathrm{~h}$ incubation time and related to the corresponding number of cells, reached levels more than 6 times higher $\left(772 \pm 6\right.$ units per number $\left(\times 10^{9}\right)$ of cells) than in V. splendidus LGP32 CSF (124 \pm 2 units per number $\left(\times 10^{9}\right)$ of cells). Second, the first detection of metalloprotease activities occurred in CSF from both strains from 12 to $16 \mathrm{~h}$ in MB cultures, corresponding to $10^{8}$ CFU $\mathrm{ml}^{-1}$ concentrations. Earlier in the culture period, metalloprotease activities were undetectable in the CSF, but $V$. splendidus and $V$. aestuarianus metalloprotease production was clearly triggered when cultures reached a threshold concentration of $7.210^{7} \mathrm{CFU} \mathrm{ml}{ }^{-1}$ for both cultures. These results suggest that the production of these virulence factors involves a celldensity dependent phenomenon and is likely induced by a quorum sensing system.

Our study therefore confirms the presence of a bacterial quorum sensing system, acting through the release of soluble communicator molecules that allow intercellular communication contributing to the regulation of cell division and gene expression. We tested the hypothesis of a quorum-sensing system regulating metalloprotease gene expression (virulence) in vitro, using the $0.22 \mu \mathrm{m}$ filtered cell-free and non-proteolytically active supernatant from a $20 \mathrm{~h}$ culture of the $V$. splendidus LGP32 $\Delta v s m-\Delta 1062$ strain as a conditioned medium likely to contain autoinducerlike substances.

The results from the growth and metalloprotease activity experiments (Figure 2) allowed us to accurately determine the relevant culture concentrations to study. The first concentration, of $10^{8}$ CFU $\mathrm{ml}^{-1}$, corresponds to the culture concentration with a positive metalloprotease activity for both Vibrio. The second concentration, of $10^{5} \mathrm{CFU} \mathrm{ml}^{-1}$, was lower than the previously recorded

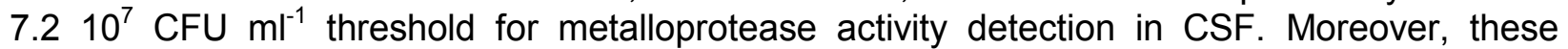
results (Figure 2) allowed us to determine the minimal optimal age of the cultures to study: cultures aged $1.5 \mathrm{~h}$ offered two advantages: i/ avoidance of the significant production of endogenous autoinducers by bacteria in each inoculum used, which could mask the effect of exogenous autoinducers potentially present in the conditioned medium; and ii/ maintainance of bacterial concentrations close to those of the inocula, since generation times of 41 min and 60 min had already been determined for the studied $V$. splendidus and $V$. aestuarianus strains, respectively. 
The normalized relative quantification of $v s m$ and vam expression level in different $1.5 \mathrm{~h}$ cultures allowed us to corroborate the quorum sensing hypothesis. Firstly, concerning V. splendidus LGP32 cultures, no vsm mRNA was detected in either conditioned or MB media at the low bacterial concentration $\left(10^{5} \mathrm{CFU} \mathrm{ml}{ }^{-1}\right)$. A 4.4-fold increase was revealed in the conditioned culture compared with the MB media at the high bacterial concentration $\left(10^{8} \mathrm{CFU}\right.$ $\mathrm{ml}^{-1}$ ). These results indicate that the $V$. splendidus mutant produced autoinducer-like activity available to $V$. splendidus LGP32 and capable of regulating vsm expression.

Secondly, concerning $V$. aestuarianus 02/041 cultures, the first detection of vam metalloprotease mRNA occurred $1.5 \mathrm{~h}$ after the addition of the cell-free conditioned medium,

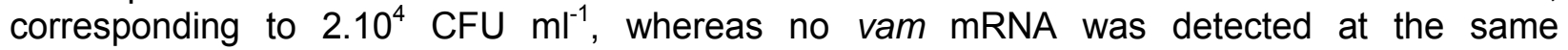
concentration in MB cultures. The use of conditioned medium provoked spectacular fold increases of vam transcripts of at least $2.410^{5}$ and 218 at low and high $\left(10^{8} \mathrm{CFU} \mathrm{ml}^{-1}\right)$ bacterial concentrations, respectively, when comparing the effect of the two media. $V$. aestuarianus is thus capable of responding to molecules produced by this $V$. splendidus strain present in culture supernatant fluids. Finally, a $6.710^{4}$-fold increase of $F$ value was found when comparing the relative metalloprotease gene expression level of $V$. aestuarianus to $V$. splendidus at high bacterial concentration in the conditioned medium. These results showed that the $V$. splendidus mutant produced an autoinducer-like activity that could act interspecifically through the $V$. aestuarianus 02/041 signaling system, thereby regulating and inducing vam expression even at the lowest concentration under the threshold value for metalloprotease activity detection. These results could partly explain why the $V$. aestuarianus 02/041 strain exhibited higher virulence when injected simultaneously with the $V$. splendidus LGP32 strain into $C$. gigas oysters, than when $V$. aestuarianus was injected alone at the same concentration (Saulnier, et al., 2010). Our experiments confirmed for the first time that $V$. splendidus LGP32 is able to produce an autoinducer-like substance that displays both intra- and interspecific effects on the expression of the two metalloprotease genes, vsm and vam.

A number of different approaches could be taken in future research to identify which autoinducers are produced by $V$. splendidus and which are able to modulate $V$. splendidus and $V$. aestuarianus metalloprotease gene expression. First, biosensor strains that report autoinducer activities could be employed. Such strains do not produce their own autoinducers but contain a reporter gene that can be induced when supplied with an exogenous signal molecule. Different biosensor strains are available targeting a variety of autoinducers, for example $V$. harveyi JAF375 (HAl-1- ${ }^{-}$Al-2- $\left.{ }^{-}, \mathrm{CAl}-1^{+}\right)$, V. harveyi JMH597 ( $\left.\mathrm{HAl}-1^{-}, \mathrm{Al}-2^{+}, \mathrm{CAl}-1^{-}\right)$ and $V$. harveyi JMH612 (HAl-1 ${ }^{+}, \mathrm{Al}^{-2}$, CAl-1') (Bassler, et al., 1997; Defoirdt, et al., 2008; Henke, Bassler, 2004a; Yang, et al., 2011). Furthermore, normal-phase high-performance liquid chromatography (HPLC) could be carried out to identify the autoinducers present in ECPs. Finally, mutagenesis could be performed targeting genes involved in the quorum sensing system, as allelic exchange strategies have been seen to be efficient on $V$. splendidus strain LGP32 using suicide vectors (Le Roux, et al., 2007).

To conclude, these results suggested that a quorum sensing system causes the modulation of vsm and vam metalloprotease genes expression in our culture conditions. This quorum sensing phenomenon had intra- and interspecific effects on virulence factor expression when using $V$. splendidus and $V$. aestuarianus strain models. This common cell-to-cell communication between these two bacteria could contribute to the synergistic effect previously described between these two C. gigas oyster pathogens (Saulnier, et al., 2010). More bacterial strains commonly found around or in oyster's environments, will have to be tested in further crossstimulation assays in order to assess the specificity of the quorum sensing system involved in the metalloprotease virulence factor expression. Using a quorum sensing inhibitor could reveal 
much information about the virulence modulation and residual pathogenicity of marine bacteria pathogenic for oysters. Our experimental approaches performed in pure cultures could be extended to in vivo studies. Knowing the abundance and complexity of the oyster endogenous bacterial flora and the physiological permeability of internal hemolymph tissue to surrounding bacterioplankton (De Decker, Saulnier, 2011), bacterial interaction studies involving the quorum sensing system could contribute to our knowledge on bacterial competition or collaboration mechanisms leading to bacterial pathogenesis (Duan, et al., 2003). These findings offer many new directions for study of the modulation of bacterial virulence mechanisms involved in $C$. gigas mortality events.

\section{Acknowledgments}

We thank Dr. F. Le Roux for providing the mutant Vibrio splendidus LGP32 strains. The authors would also like to thank P. Haffner for his technical support and Dr. Y. Gueguen for his critical reading of the manuscript. The manuscript was revised by the Bureau de Traduction de I'Université, UBO, Brest, to whom we are grateful.

\section{References}

Arias, C.R., Macian, M.C., Aznar, R., Garay, E., Pujalte, M.J., 1999. Low incidence of Vibrio vulnificus among Vibrio isolates from sea water and shellfish of the western Mediterranean coast. J Appl Microbiol. 86, 125-134.

Azandégbé, A., Garnier, M., Andrieux-Loyer, F., Kérouel, R., Philippon, X., Nicolas, J., 2010. Occurrence and seasonality of Vibrio aestuarianus in sediment and Crassostrea gigas haemolymph at two oyster farms in France. Dis Aquat Org. 91, 213-221.

Bassler, B.L., 2002. Small talk. Cell-to-cell communication in bacteria. Cell. 109, 421-424.

Bassler, B.L., Greenberg, E.P., Stevens, A.M., 1997. Cross-species induction of luminescence in the quorum-sensing bacterium Vibrio harveyi. J Bacteriol. 179, 4043-4045.

Beaz Hidalgo, R., Cleenwerck, I., Balboa, S., De Wachter, M., Thompson, F.L., Swings, J., De Vos, P., Romalde, J.L., 2008. Diversity of Vibrios associated with reared clams in Galicia (NW Spain). Syst Appl Microbiol. 31, 215.

Binesse, J., Delsert, C., Saulnier, D., Champomier-Verges, M.C., Zagorec, M., MunierLehmann, H., Mazel, D., Le Roux, F., 2008. The metalloprotease Vsm is the main toxic factor for Vibrio splendidus extracellular products. Appl Environ Microbiol. 74, 71087117.

De Decker, S., Saulnier, D., 2011. Vibriosis induced by experimental cohabitation in Crassostrea gigas: Evidence of early infection and down-expression of immune-related genes. Fish Shellfish Immun. 30, 691-699.

De Decker, S., Normand, J., Saulnier, D., Pernet, F., Castagnet, S., Boudry, P., 2011. Responses of diploid and triploid Pacific oysters Crassostrea gigas to Vibrio infection in relation to their reproductive status. J Invertebr Pathol. 106, 179-191.

Defoirdt, T., Verstraete, W., Bossier, P., 2008. Luminescence, virulence and quorum sensing signal production by pathogenic Vibrio campbellii and Vibrio harveyi isolates. J Appl Microbiol. 104, 1480.

Defoirdt, T., Bossier, P., Sorgeloos, P., Verstraete, W., 2005. The impact of mutations in the quorum sensing systems of Aeromonas hydrophila, Vibrio anguillarum and Vibrio 
harveyi on their virulence towards gnotobiotically cultured Artemia franciscana. Environ Microbiol. 7, 1239-1247.

Defoirdt, T., Boon, N., Sorgeloos, P., Verstraete, W., Bossier, P., 2007. Alternatives to antibiotics to control bacterial infections: luminescent vibriosis in aquaculture as an example. Trends Biotechnol. 25, 472-479.

Denkin, S.M., Nelson, D.R., 2004. Regulation of Vibrio anguillarum empA metalloprotease expression and its role in virulence. Appl Environ Microbiol. 70, 4193-4204.

Duan, K., Dammel, C., Stein, J., Rabin, H., Surette, M.G., 2003. Modulation of Pseudomonas aeruginosa gene expression by host microflora through interspecies communication. Mol Microbiol. 50, 1477-1491.

Fuqua, C., Greenberg, E.P., 1998. Self perception in bacteria: quorum sensing with acylated homoserine lactones. Curr Opin Microbiol. 1, 183-189.

Garnier, M., Labreuche, Y., Garcia, C., Robert, M., Nicolas, J.L., 2007. Evidence for the involvement of pathogenic bacteria in summer mortalities of the Pacific oyster Crassostrea gigas. Microb Ecol. 53, 187-196.

Gay, M., Berthe, F.C., Le Roux, F., 2004a. Screening of Vibrio isolates to develop an experimental infection model in the Pacific oyster Crassostrea gigas. Dis Aquat Org. 59, 49-56.

Gay, M., Renault, T., Pons, A.M., Le Roux, F., 2004b. Two Vibrio splendidus related strains collaborate to kill Crassostrea gigas: taxonomy and host alterations. Dis Aquat Org. 62, 65-74.

Gomez-Gil, B., Roque, A., Lacuesta, B., Rotllant, G., 2010. Diversity of vibrios in the haemolymph of the spider crab Maja brachydactyla. J Appl Microbiol. 109, 918.

Grimes, D., Johnson, C., Dillon, K., Flowers, A., Noriea, N., Berutti, T., 2009. What genomic sequence information has revealed about Vibrio ecology in the ocean-A review. Microb Ecol. 58, 447.

Henke, J.M., Bassler, B.L., 2004a. Three parallel quorum-sensing systems regulate gene expression in Vibrio harveyi. J Bacteriol. 186, 6902-6914.

Henke, J.M., Bassler, B.L., 2004b. Quorum sensing regulates type III secretion in Vibrio harveyi and Vibrio parahaemolyticus. J Bacteriol. 186, 3794-3805.

Higgins, D.A., Pomianek, M.E., Kraml, C.M., Taylor, R.K., Semmelhack, M.F., Bassler, B.L., 2007. The major Vibrio cholerae autoinducer and its role in virulence factor production. Nature. 450, 883.

Kaprelyants, A.S., Kell, D.B., 1996. Do bacteria need to communicate with each other for growth? Trends Microbiol. 4, 237-242.

Labreuche, Y., Le Roux, F., Henry, J., Zatylny, C., Huvet, A., Lambert, C., Soudant, P., Mazel, D., Nicolas, J.-L., 2010. Vibrio aestuarianus zinc metalloprotease causes lethality in the Pacific oyster Crassostrea gigas and impairs the host cellular immune defenses. Fish \& Shellfish Immunology. 29, 753.

Le Roux, F., Austin, B., 2006. Vibrio splendidus. In: Thompson, F.L., Austin, B., Swings, J. (Eds.), The Biology of Vibrios. ASM Press, Washington, DC, pp. 285-296.

Le Roux, F., Binesse, J., Saulnier, D., Mazel, D., 2007. Construction of a Vibrio splendidus mutant lacking the metalloprotease gene vsm by use of a novel counterselectable suicide vector. Appl Environ Microbiol. 73, 777-784.

Le Roux, F., Gay, M., Lambert, C., Nicolas, J.L., Gouy, M., Berthe, F., 2004. Phylogenetic study and identification of Vibrio splendidus-related strains based on gyrB gene sequences. Dis Aquat Org. 58, 143-150.

Le Roux, F., Mohamed, Z., Chakroun, N., Binesse, J., Saulnier, D., Bouchier, C., Zidane, N., Ma, L., Rusniok, C., Lajus, A., Buchrieser, C., Médigue, C., Polz, M.F., Mazel, D., 2009. Genome sequence of Vibrio splendidus: an abundant planctonic marine species with a large genotypic diversity. Environ Microbiol. 11, 1959-1970. 
Macián, M., Garay, E., González-Candelas, F., Pujalte, M., Aznar, R., 2000. Ribotyping of Vibrio populations associated with cultured oysters (Ostrea edulis). Syst Appl Microbiol. 23, 409-417.

McDougald, D., Rice, S., Kjelleberg, S., 2007. Bacterial quorum sensing and interference by naturally occurring biomimics. Anal Bioanal Chem. 387, 445.

Miller, M.B., Bassler, B.L., 2001. Quorum Sensing in Bacteria. Annu Rev Microbiol. 55, 165-199.

Mok, K., Wingreen, N., Bassler, B., 2003. Vibrio harveyi quorum sensing: a coincidence detector for two autoinducers controls gene expression. EMBO J. 22, 870-881.

Montes, M., Farto, R., Perez, M.J., Armada, S.P., Nieto, T.P., 2006. Genotypic diversity of Vibrio isolates associated with turbot (Scophthalmus maximus) culture. Res Microbiol. 157, 487.

Montes, M., Farto, R., Pérez, M.J., Nieto, T.P., Larsen, J.L., Christensen, H., 2003. Characterization of Vibrio strains isolated from turbot (Scophthalmus maximus) culture by phenotypic analysis, ribotyping and $16 \mathrm{~S}$ rRNA gene sequence comparison. J Appl Microbiol. 95, 693.

Pujalte, M.J., Ortigosa, M., Macián, M.C., Garay, E., 1999. Aerobic and facultative anaerobic heterotrophic bacteria associated to Mediterranean oysters and seawater. Int Microbiol. 2, 259-266.

Ren, D., Sims, J., J., Wood, T., K., 2001. Inhibition of biofilm formation and swarming of Escherichia coli by (5Z)-4-bromo-5-(bromomethylene)-3-butyl-2(5H)-furanone. Environ Microbiol. 3, 731-736.

Saulnier, D., De Decker, S., Haffner, P., 2009. Real-time PCR assay for rapid detection and quantification of Vibrio aestuarianus in oyster and seawater: A useful tool for epidemiologic studies. J Microbiol Meth. 77, 191-197.

Saulnier, D., De Decker, S., Haffner, P., Cobret, L., Robert, M., Garcia, C., 2010. A large-scale epidemiological study to identify bacteria pathogenic to Pacific oyster Crassostrea gigas and correlation between virulence and metalloprotease-like activity. Microb Ecol. 59, 787-798.

Schauder, S., Bassler, B.L., 2001. The languages of bacteria. Gene Dev. 15, 1468-1480.

Shao, C.-P., Hor, L.-I., 2001. Regulation of metalloprotease gene expression in Vibrio vulnificus by a Vibrio harveyi LuxR homologue. J Bacteriol. 183, 1369-1375.

Thompson, J.R., Pacocha, S., Pharino, C., Klepac-Ceraj, V., Hunt, D.E., Benoit, J., SarmaRupavtarm, R., Distel, D.L., Polz, M.F., 2005. Genotypic diversity within a natural coastal bacterioplankton population. Science. 307, 1311-1313.

Waters, C.M., Bassler, B.L., 2005. QUORUM SENSING: Cell-to-Cell Communication in Bacteria. Annu Rev Cell Dev Bi. 21, 319-346.

Wirth, R., Muscholl, A., Wanner, G., 1996. The role of pheromones in bacterial interactions. Trends Microbiol. 4, 96-103.

Yang, Q., Han, Y., Zhang, X.H., 2011. Detection of quorum sensing signal molecules in the family Vibrionaceae. J Appl Microbiol. 110, 1438.

Zhu, J., Miller, M.B., Vance, R.E., Dziejman, M., Bassler, B.L., Mekalanos, J.J., 2002. Quorumsensing regulators control virulence gene expression in Vibrio cholerae. P Natl Acad Sci USA. 99, 3129-3134. 
Tables

Table 1 : Bacterial strains used in this study

\begin{tabular}{|c|c|c|c|}
\hline Strain & Description & $\begin{array}{l}\text { Metalloprotease } \\
\text { activity }\end{array}$ & Reference or source \\
\hline $02 / 041$ & V. aestuarianus & + & $\begin{array}{l}\text { (Garnier, et al., } \\
\text { 2007) }\end{array}$ \\
\hline LGP32-GFP & V. splendidus LGP32 gfp $\left(\mathrm{Cm}^{r}\right)$ & + & $\begin{array}{l}\text { (De Decker, et al., } \\
\text { 2011) }\end{array}$ \\
\hline LGP32- $\Delta v s m-\Delta 1062$ & $\begin{array}{l}\text { V. splendidus } \\
\Delta 1062\end{array}$ & - & $\begin{array}{l}\text { (Binesse, et al., } \\
\text { 2008) }\end{array}$ \\
\hline
\end{tabular}

Table 2 : Primer pairs used to specifically target vsm and vam cDNA, and their amplification efficiency in real-time qPCR expression analysis.

\begin{tabular}{llllc}
\hline $\begin{array}{l}\text { Targeted } \\
\text { genes }\end{array}$ & Primers name & $\begin{array}{l}\text { Oligonucleotide sequences } \\
\left(5^{\prime}-3^{\prime}\right)\end{array}$ & $\begin{array}{l}\text { qPCR } \\
\text { efficiency } \\
(\%)\end{array}$ & $\begin{array}{l}\text { Amplicon } \\
\text { length (bp) }\end{array}$ \\
\hline$v s m$ & $\begin{array}{l}\text { S-METVS2F } \\
\text { S-METVS2R }\end{array}$ & $\begin{array}{l}\text { ACCTAAGCGGGAACCAATCT } \\
\text { GGAAGGGCGACAGTCGTAA }\end{array}$ & 99.3 & 159 \\
\multirow{4}{*}{ am } & $\begin{array}{l}\text { S-METVA2F } \\
\text { S-METVA2R }\end{array}$ & $\begin{array}{l}\text { GACCACTTGGGAAGGCTTGAA } \\
\text { S-METTTCACCGCACTAT }\end{array}$ & 103.7 & 159 \\
\hline
\end{tabular}


Figure 1 : Standard curves for $V$. splendidus LGP32-GFP (black squares) and $V$. aestuarianus 02/041 (gray diamonds) real-time PCR in 1:10 serial dilutions of their DNA, corresponding to 1.7 $10^{3}$ to $1.710^{8}$ and $2.610^{2}$ to $2.610^{7} \mathrm{CFU}$-equivalent genomes number $\mathrm{ml}^{-1}$ of the initial samples, respectively. Standard curves were generated by plotting the CFU-equivalent genomes number $\mathrm{ml}^{-1}$ on the mean threshold cycle $(\mathrm{Ct})$ value obtained from triplicate assays.

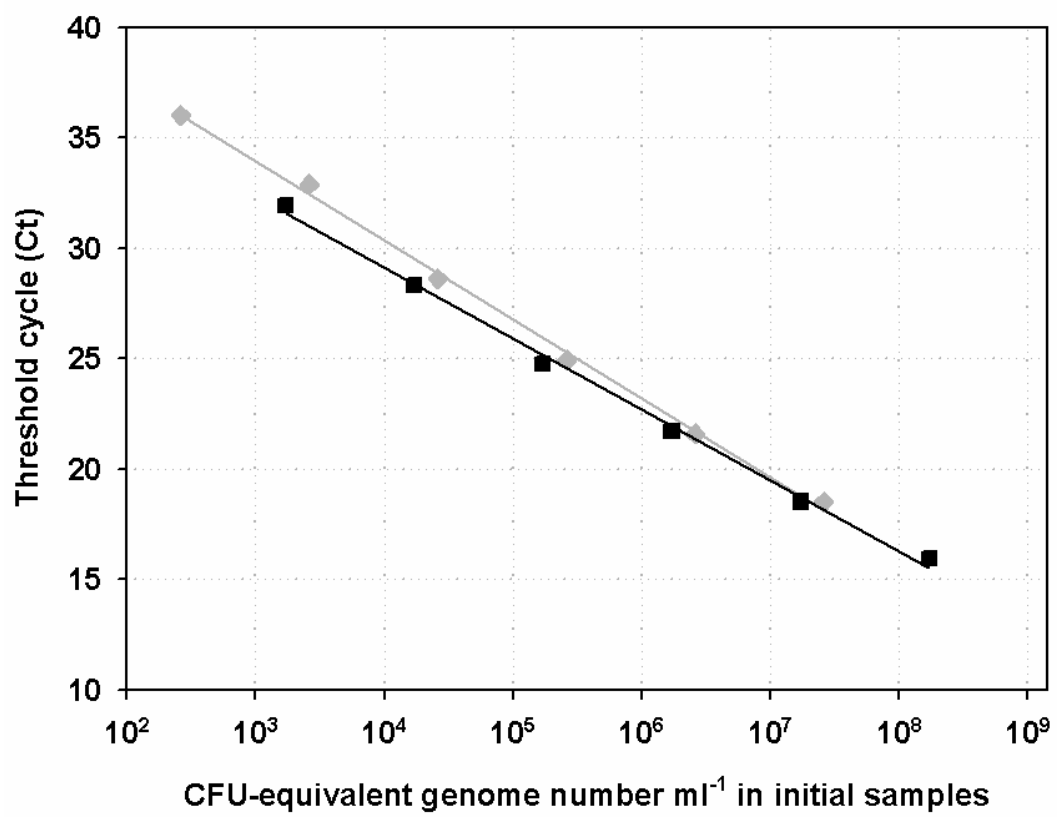

Figure 2 A : Growth curves of the two virulent Vibrio strains LGP32-GFP (black line) and 02/041 (gray line), quantified by real-time qPCR (CFU-equivalent genomes number $\mathrm{ml}^{-1}$ ). Plotted values are means $( \pm S D)$ obtained from three different cultures $(n=3$ for each point).

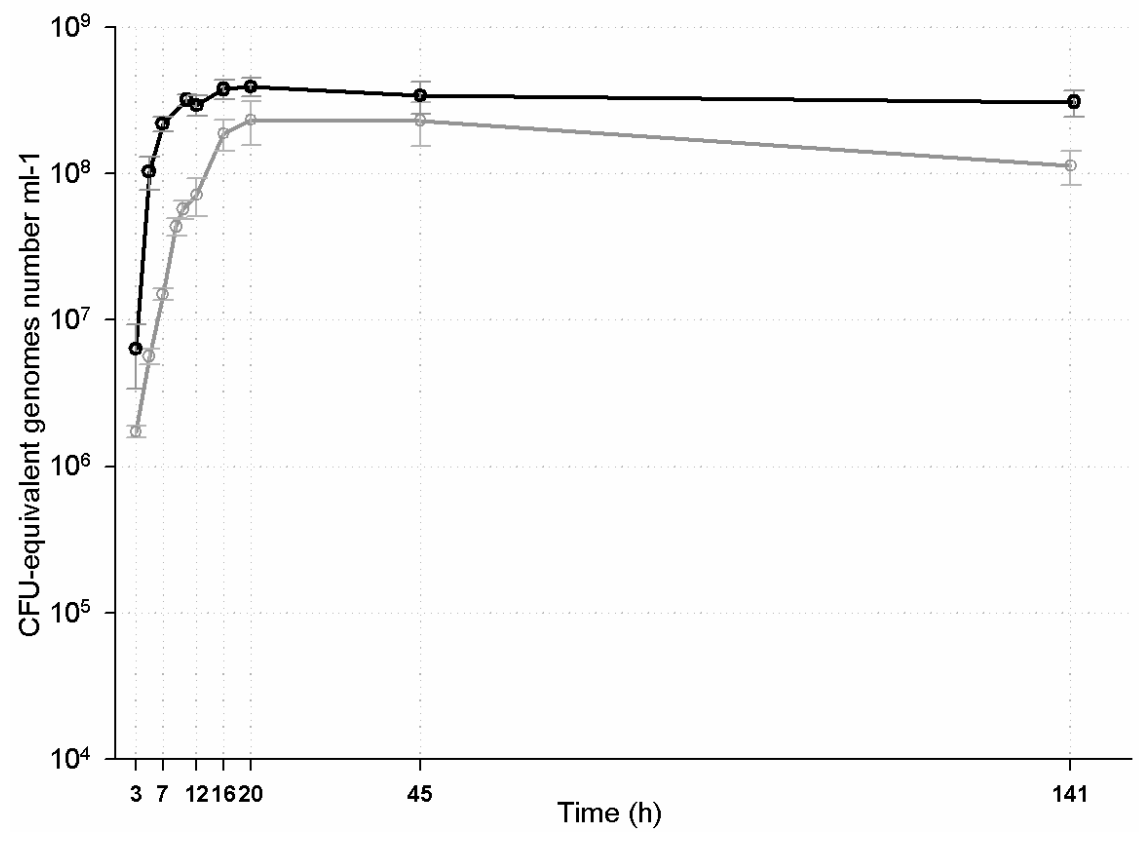


Figure 2 B : Metalloprotease-like activity in culture supernatant fluids from LGP32-GFP (black line) and $02 / 041$ (gray line) Vibrio strains. Results are expressed as the metalloprotease activity per number of $10^{9}$ CFU-equivalent genomes quantified by GPCR (units per number of cells). Metalloprotease activity was calculated as the difference between azocaseinase activity obtained in the absence or presence of phenanthrolein. One unit of protease activity was defined as the amount of enzyme that caused an increase of 0.01 absorbance units after $2 \mathrm{~h}$ of incubation at $37^{\circ} \mathrm{C}$. Plotted values are means $( \pm S D)$ obtained from three different culture samples ( $n=3$ for each point).

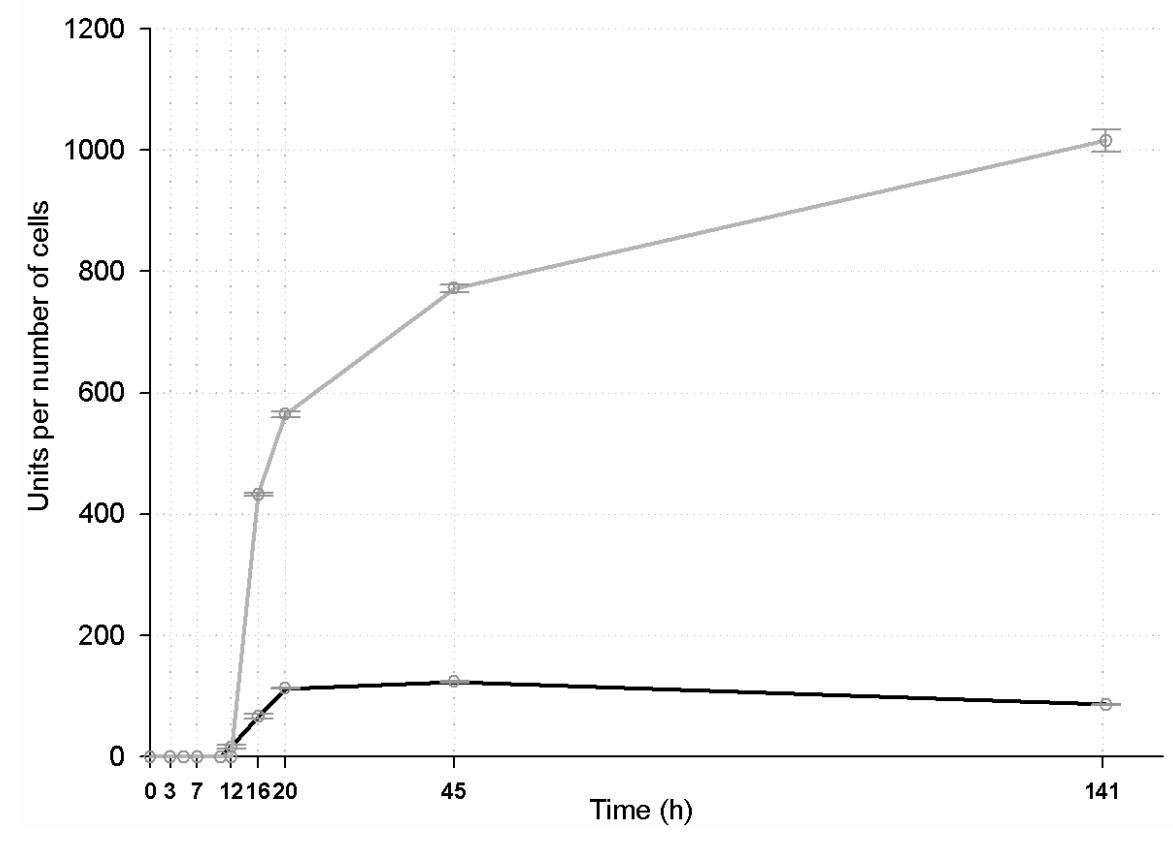

Figure $3: V$. splendidus vsm (black) and $V$. aestuarianus vam (grey) normalized relative gene expression levels (mean $\mathrm{F} \pm \mathrm{SD}$ ) calculated by the formula: $\mathrm{F}=(\mathrm{E}+1)^{40-\mathrm{Ct}} / \mathrm{N}$ quantified by $\mathrm{RT}-\mathrm{qPCR}$ in Marine Broth medium cultures $(A)$ and in conditioned medium cultures $(B)$. L: low bacterial concentration ranged between $2.010^{4}$ and $1.610^{5}$ CFU-equivalent genomes number $\mathrm{ml}^{-1} ; \mathrm{H}$ : high bacterial concentration ranged between $2.810^{7}$ and $1.210^{9} \mathrm{CFU}$-equivalent genomes number $\mathrm{ml}^{-1}$ quantified by real-time qPCR.
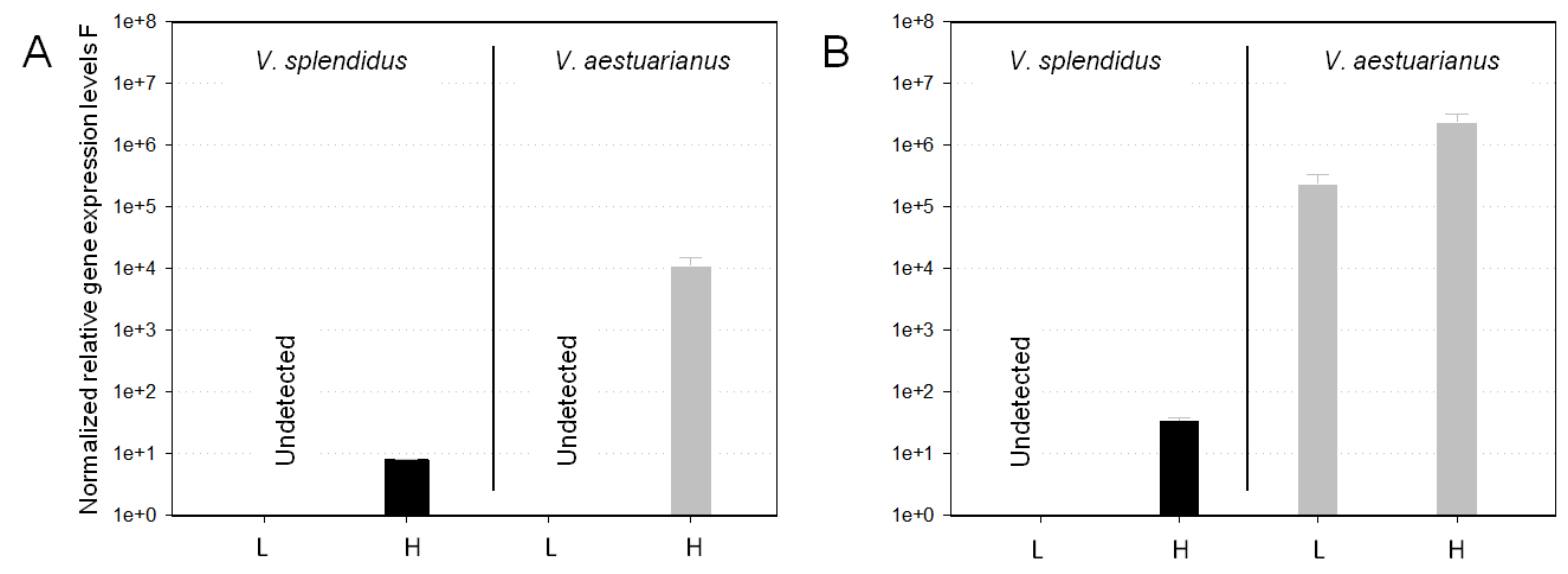